\title{
Pengaruh Etos Kerja Terhadap Kinerja Melalui Disiplin Kerja Pegawai Dinas Pekerjaan Umum dan Penataan Ruang Kota Gunungsitoli
}

\section{Impact Of Work Ethic On Employee Performance Through The Work Discipline Of Departement of Public Work and Spatial Planning of Gunungsitoli}

\author{
Alfred Samuel Zebua* \\ Universitas Terbuka, Indonesia
}

Disubmit: 29 September 2021; Diproses: 30 September 2021; Diaccept: 23 Oktober 2021; Dipublish: 02 Desember 2021

*Corresponding author: E-mail: alfredsamuelut@gmail.com

\begin{abstract}
Abstrak
Peningkatan kinerja pegawai Dinas Pekerjaan Umum dan Penataan Ruang Kota Gunungsitoli sebagai bagian dari pemerintah Kota Gunungsitoli merupakan suatu keharusan sebagai perwujudan pelayanan masyarakat sebagai pembina, pengayom dan pemerhati masalah-masalah pekerjaan umum. Penelitian ini bertujuan untuk mengetahui dan menganalisis pengaruh etos kerja terhadap kinerja melalui disiplin kerja pegawai Dinas Pekerjaan Umum dan Penataan Ruang Kota Gunungsitoli. Populasi penelitian sebanyak 30 orang pegawai Dinas Pekerjaan Umum dan Penataan Ruang Kota Gunungsitoli. Teknik pengambilan sampel yang digunakan dalam penelitian ini dengan menggunakan teknik total sampling dimana seluruh populasi menjadi sampel penelitian. Teknik pengumpulan data menggunakan kuesioner. Kuesioner telah diuji coba dan dinyatakan valid dan reliabel. Data dianalisis dengan analisis statistik deskriptif dan analisis jalur (path analysis). Hasil penelitian menunjukkan secara parsial etos kerja berpengaruh langsung terhadap disiplin kerja pegawai Dinas Pekerjaan Umum dan Penataan Ruang Kota Gunungsitoli, secara parsial etos kerja berpengaruh langsung terhadap kinerja pegawai Dinas Pekerjaan Umum dan Penataan Ruang Kota Gunungsitoli, secara parsial disiplin kerja berpengaruh langsung terhadap kinerja pegawai Dinas Pekerjaan Umum dan Penataan Ruang Kota Gunungsitoli dan etos kerja berpengaruh terhadap kinerja melalui disiplin kerja pegawai Dinas Pekerjaan Umum dan Penataan Ruang Kota Gunungsitoli.
\end{abstract}

Kata Kunci: Etos Kerja; Disiplin Kerja; Kinerja

\begin{abstract}
Improving the Employee Performance of Department of Public Works and Spatial Planning of Gunungsitoli as part of the Gunungsitoli City government is a must as a manifestation of community service as a builder, protector and observer of public works issues. The purpose of this study is to determine and analyze the impact of work ethic on performance through the work discipline on Employee Performance through the Work Discipline of Department of Public Works and Spatial Planning of Gunungsitoli. The Sampling techniques was used in this study, with a total of 30 samples drawn from the entire population. Data collection techniques using questionnaires. The questionnaire has been tested and declared valid and reliable. The data is analyzed with descriptive statistical analysis and path analysis. The findings revealed that the work ethic has a positive and significant impact on work discipline of Department of Public Works and Spatial Planning of Gunungsitoli, the the work ethic directly affects has a positive and significant impact on employee performance of Department of Transportation of Gunungsitoli. The findings revealed that the work ethic partially affects the work discipline of employee performance of Department of Public Works and Spatial Planning of Gunungsitoli, partially the work ethic directly affects the employee performance of Department of Public Works and Spatial Planning of Gunungsitoli, partially the work discipline directly affects the employee performance of Department of Public Works and Spatial Planning of Gunungsitoli and the work ethic affects performance through the work discipline
\end{abstract}

Keywords: Work Ethic; Work Discipline; Employee Performance 


\section{PENDAHULUAN}

Pemerintah daerah sebagai tonggak pelaksana pembangunan daerah sebaiknya menyelenggarakan manajemen pembangunan yang baik. Pembangunan yang dimaksud yaitu menyentuh segala bidang pembangunan(Putra et al., 2014). Keberadaan Dinas Pekerjaan Umum dan Penataan Ruang Kota Gunungsitoli sebagai lembaga pemerintahan wajib melaksanakan tugas di bidang pelayanan masyarakat yaitu: sebagai pembina, pengayom dan pemerhati masalahmasalah pekerjaan umum.

Dinas Pekerjaan Umum dan Penataan Ruang Kota Gunungsitoli memiliki kewenangan untuk mengatur rumah tangga organisasi, serta melaksanakan tugas yang telah diberikan oleh Walikota Gunungsitoli, yang membawahi beberapa bidang, antara lain: Bidang Sumber Daya Air, Bidang Bina Marga, Bidang Cipta Karya, Bidang Penataan Ruang dan Bidang Peralatan. Kinerja tinggi karyawan sangat dibutuhkan dalam melayani kepentingan masyarakat(Setiawan \& Dewi, 2014)

Secara umum, kinerja adalah hasil kerja yang dicapai oleh seseorang pegawai dalam melaksanakan tugas yang dibebankan kepadanya(Nur et al., 2019). Kinerja merupakan prestasi kerja yang dihasilkan oleh pegawai sesuai dengan peran dan tugas yang diembannya dalam instansi(Karundeng, 2013). Lebih lanjut, kinerja merupakan tindakan atau pelaksanaan tugas yang dapat diukur dalam ukuran kinerja secara umum meliputi: kualitas kerja, kuantitas kerja, pengetahuan tentang pekerjaan, dan perencanaan kerja(Murniaty \& Absah,
2012). Kinerja pegawai penting untuk diperhatikan oleh setiap organisasi karena manusia, dalam hal ini pegawai merupakan faktor utama dalam proses kerja yang pada akhirnya akan menjadikan kinerja instansi secara keseluruhan berlangsung secara baik atau tidak(Manuho et al., 2015). Karyawan yang memiliki kinerja tinggi ditandai dengan beberapa hal, antara lain: karyawan dapat menyelesaikan tugas dengan tepat dan cepat, karyawan bersedia mematuhi peraturan yang berlaku di perusahaan(Dewi \& Utomo, 2015), karyawan sanggup bekerja dalam waktu yang sudah ditentukan, karyawan dapat bekerjasama dengan karyawan lain dalam menyelesaikan pekerjaan atau suatu tugas yang ditentukan oleh perusahaan (Hardiansyah, 2017)

Data capaian kinerja Dinas Pekerjaan Umum dan Penataan Ruang Kota Gunungsitoli pada tahun 2019 menunjukkan 7 indikator dari 14 indikator tergolong rendah. Rendahnya pencapaian 7 indikator dari 14 indikator capaian kinerja tahun 2019 Dinas Pekerjaan Umum dan Penataan Ruang Kota Gunungsitoli pada tahun 2019 merupakan akumulasi dari kinerja pegawai Dinas Pekerjaan Umum dan Penataan Ruang Kota Gunungsitoli. Kinerja pegawai diukur melalui nilai sasaran keja pegawai yang menunjukkan nilai kinerja pegawai Dinas Pekerjaan Umum dan Penataan Ruang Kota Gunungsitoli pada periode 2017-2019 yang terjadi penurunan pada tahun 2019 . Penurunan kinerja pegawai diduga mulai menurunnya etos kerja pegawai yang 
dibarengi kurangnya penerapan disiplin kerja pegawai(Sagala, 2018).

Etos kerja pegawai Dinas Pekerjaan Umum dan Penataan Ruang Kota Gunungsitoli dapat dilihat dari kerja keras mereka seperti bekerja lembur, namun beberapa pegawai tidak memanfaatkan jam kerja yang ada dan cenderung mengurangi jam kerja mereka. Pegawai yang menunjukkan etos kerja terbaik pada umumnya memiliki disiplin kerja dimana memiliki kemampuan serta kesadaran sendiri untuk mengikuti peraturan yang berlaku(Amanahtuzuriah et al., n.d.). (Bawelle \& Sepang, 2016)berpendapat bahwa disiplin adalah setiap kesediaan seseorang yang timbul dengan kesadaran sendiri untuk mengikuti peraturanperaturan yang berlaku dalam organisasi. Tingkat disiplin pegawai Dinas Pekerjaan Umum dan Penataan Ruang Kota Gunungsitoli yang rendah dimana pegawai tidak begitu mengindahkan peraturan yang ada, tidak adanya sanksi yang berat untuk pegawai yang melanggar, serta perhatian yang kurang dari atasan kepada bawahan

Menurut (Dewi \& Utomo, 2015) seorang karyawan dikatakan memiliki disiplin kerja yang tinggi apabila memenuhi kriteria berdasarkan sikap, norma, dan tanggung jawab. Kriteria berdasarkan sikap mengacu pada mental dan perilaku karyawan yang berasal dari kesadaran atau kerelaan dirinya sendiri dalam melaksanakan tugas dan peraturan perusahaaan(Robert Kreitner, 2014). Kriteria berdasarkan norma terkait peraturan tentang apa yang boleh dan apa yang tidak boleh dilakukan oleh para karyawan selama dalam
perusahaan(Setiawan \& Dewi, 2014). Kriteria berdasarkan tanggung jawab merupakan kemampuan dalam menjalankan tugas dan peraturan dalam perusahaan(Andharini et al., 2016).

Berdasarkan fenomena gap dan research gap yang telah dijelaskan, maka penulis tertarik untuk melakukan penelitian tentang Pengaruh Etos Kerja Terhadap Kinerja Melalui Disiplin Kerja Pegawai Dinas Pekerjaan Umum dan Penataan Ruang Kota Gunungsitoli

\section{METODE PENELITIAN}

Penelitian ini menggunakan pendekatan deskriptif kuantitatif. Berdasarkan permasalahan yang diteliti, penelitian ini digolongkan kepada bentuk penelitian kausal asosiatif, yakni penelitian yang bertujuan untuk mengetahui pengaruh antara variabel bebas terhadap variabel terikat. Sifat penelitian ini adalah deskriptif eksplanatori. Penelitian ini menggunakan mode analisis jalur (path analysis) dikarenakan diantara variabel dependend dan variabel independen terdapat variabel intervening yang mempengaruhi kedua variabel tersebut. Dalam penelitian ini, peneliti membagikan kuesioner kepada ke pegawai Dinas Pekerjaan Umum dan Penataan Ruang Kota Gunungsitoli sebagai sampel penelitian. Populasi dari penelitian ini adalah seluruh pegawai Dinas Pekerjaan Umum dan Penataan Ruang Kota Gunungsitoli yang berjumlah 30 orang. Dengan demikian jumlah responden yang digunakan dalam penelitian ini sebanyak 30 orang, sehingga penelitian ini disebut penelitian populasi 


\section{HASIL DAN PEMBAHASAN}

Berdasarkan hasil analisiss menunjukkan nilai Standardized Coefficients Beta sebesar 0,631 dimana hubungan etos kerja terhadap disiplin kerja sebesar 0,631. Nilai signifikan variabel etos kerja (X) sebesar 0.000 lebih kecil dari 0,05. Dari data tersebut dapat disimpulkan bahwa regresi model I adalah etos kerja (X) berpengaruh langsung dan signifikan terhadap disiplin kerja (Z). Persamaan regresi model I adalah:

$$
\text { Y=b1+adisiplilin kerja + e }
$$

Berdasarkan hasil analisis jalur yang dilakukan pada tabel unstandarized coefficient diperoleh persamaan I sebagai berikut:

$$
\mathrm{Y}=16,237+1,414+\mathrm{e}
$$

Persamaan diatas dapat dijelaskan sebagai berikut:

a) Konstanta sebesar 16,237

Apabila variabel etos kerja kerja tetap dan tidak berubah maka disiplin kerja bernilai positif.

b) Koefisien regresi etos kerja (X) sebesar 1,414

Nilai positif tersebut menunjukkan bahwa jika ada peningkatan kualitas etos kerja maka dapat meningkatkan disiplin kerja pegawai.

Dari uraian di atas maka dapat disimpulkan bahwa etos kerja berpengaruh terhadap disiplin kerja pegawai Dinas Pekerjaan Umum dan Penataan Ruang Kota Gunungsitoli.

Hasil Uji Koefisien Determinasi $\left(\mathrm{R}^{2}\right)$ besarnya nilai R Square adalah sebesar
0,399, hal ini menunjukkan bahwa 39,9\% variabel disiplin kerja dapat dijelaskan oleh etos kerja. Sementara sisanya $60,10 \%$ merupakan kontribusi dari variabelvariabel lain yang tidak dimasukkan dalam penelitian. Sementara untuk nilai $\mathrm{e} 1=$

$$
\sqrt{(1-0399)}=0,775 \text {. Dengan }
$$

demikian diperoleh diagram jalur model struktur I sebagai berikut

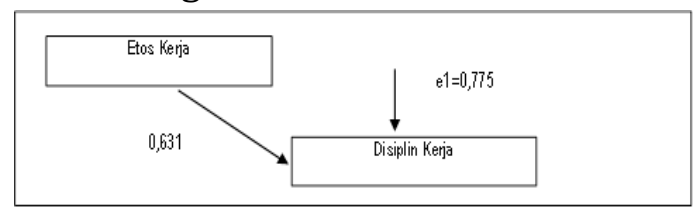

Gambar 1 Analisis Jalur I

Hasil Uji Analisis Jalur II

Berdasarkan hasil analisis menunjukkan nilai Standardized Coefficients Beta untuk variabel etos kerja sebesar 0,492 dan variabel disiplin kerja sebesar 0,337. Nilai signifikan variabel etos kerja (X) sebesar 0.006 lebih kecil dari 0,05 dan nilai signifikan variabel disiplin kerja (Z) sebesar 0.049 lebih kecil dari 0,05. Dari data tersebut dapat disimpulkan bahwa regresi model II adalah etos kerja (X) berpengaruh signifikan terhadap kinerja (Y) melalui disiplin kerja (Z) pegawai Dinas Pekerjaan Umum dan Penataan Ruang Kota Gunungsitoli. Persamaan regresi model 1I yaitu:

$\mathrm{Y}=\mathrm{b} 2+$ betos kerja + bdisiplin kerja $+\mathrm{e}$

Berdasarkan hasil analisis jalur yang dilakukan pada tabel unstandarized coefficient diperoleh persamaan II sebagai berikut: 
$\mathrm{Y}=8.033+1,026+0,314+\mathrm{e}$

Persamaan diatas dapat dijelaskan sebagai berikut:

a) Konstanta sebesar 8.033

Apabila variabel etos kerja dan disiplin kerja tetap dan tidak berubah maka kinerja bernilai positif.

b) Koefisien regresi etos kerja (Z) sebesar 1,026

Nilai positif tersebut menunjukkan bahwa jika ada peningkatan etos kerja maka dapat meningkatkan kinerja.

c) Koefisien regresi disiplin kerja (Z) sebesar 0,314

Nilai positif tersebut menunjukkan bahwa jika ada peningkatan disiplin kerja maka dapat meningkatkan kineja.

Hasil Uji Koefisien Determinasi $\left(\mathrm{R}^{2}\right)$ besarnya nilai RSquare adalah sebesar 0,566, hal ini menunjukkan bahwa 56,6\% variabel kinerja dapat dijelaskan oleh etos kerja dan disiplin kerja. Sementara sisanya $43,40 \%$ merupakan kontribusi dari variabel-variabel lain yang tidak dimasukkan dalam penelitian. Sementara untuk nilai e2 = $\sqrt{(1-0,566)}=0,659$.

Dengan demikian diperoleh diagram jalur model struktur II sebagai berikut:

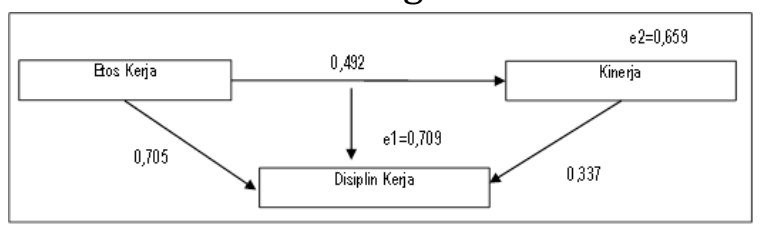

Gambar 2 Analisis Jalur II

Dari data diperoleh bahwa pengaruh langsung yang diberikan variabel etos kerja $(\mathrm{X})$ terhadap variabel kinerja $(\mathrm{Y})$ sebesar 0,492. Sedangkan pengaruh tidak langsung etos kerja terhadap kinerja ( $\mathrm{Y}$ ) melalui disiplin kerja (Z) memiliki nilai $0,705 \times 0,337=0,238$. Dari perhitungan keseluruhan variabel etos kerja (X) terhadap variabel kinerja $(\mathrm{Y})$ merupakan pengaruh langsung yang ditambah dengan pengaruh tidak langsung menjadi 0,492+ $0,238=0,729$. Dengan demikian dapat disimpulkan bahwa hipotesis $\mathrm{H}_{\mathrm{a} 4}$ "Etos Kerja berpengaruh terhadap kinerja melalui disiplin kerja pegawai Dinas Pekerjaan Umum dan Penataan Ruang Kota Gunungsitoli" diterima

Hasil analisis membuktikan hipotesis penelitian yang menyatakan disiplin kerja berpengaruh langsung terhadap kinerja pegawai Dinas Pekerjaan Umum dan Penataan Ruang Kota Gunungsitoli. Pegawai Dinas Pekerjaan Umum dan Penataan Ruang Kota Gunungsitoli senantiasa mematuhi jam kerja yang ditentukan sesuai dengan peaturan yang berlaku terutama pada saat pandemi covid-19.

Pegawai yang mematuhi jam kerja akan memperoleh penilaian baik pada evaluasi pegawai yang dilaksanakan oleh pejabat setiap akhir tahun berkenaan. Sedangkan pegawai yang memilki kedisiplinan rendah dalam mematuhi jam kerja akan memeproleh penilain cukup atau kurang pada evaluasi pencapaian sasaran kerja pegawai. Penilaian cukup atau kurang berpengaruh pada pencapaian kineja pegawai dan memeperoleh pembinaan dari atasan.

Pegawai Dinas Pekerjaan Umum dan Penataan Ruang Kota Gunungsitoli yang bergerak pada bidang infrastruktur pekerjaan umum dan penataan ruang selalu menguatakan kedisiplinan dalam 
menggunakan peralatan kerja. Kedisplinan kerja yang selalu diterapkan pegawai Dinas Pekerjaan Umum dan Penataan Ruang Kota Gunungsitoli memastikan tercapainya keselamatan dan kesehatan kerja di lingkungan kerja. Salah satu bentuk kediplin kerja pegawai dalam penggunaan peralatan dengan mematuhi manual kerja dan selalu seuai dengan SOP lembaga.

Penyalahgunaan manual kerja dan penyimpangan kerja dari SOP yang telah ditentukan berdampak pada pencapaian kinerja kerja pegawai. Sanksi atas penyalahgunaan dan penyimpangan kerja tergantung pada bobot kesalahan pegawai Dinas Pekerjaan Umum dan Penataan Ruang Kota Gunungsitoli. Kesalahan dengan kategori rendah akan menerima sanksi berupa teguran lisan, kesalahan dengan kategori sedang akan menerima sanksi berupa surat peringatan dan pembinaan, sedangkan kesalahan dengankategori berat akan menerima sanksi berupa pemecatan dan atau pidana penjara.

Untuk memastikan tidak adanya kesalahan atau setidaknya meminimalkan kesalahan yang terjadi selama menjalankan tugas, pegawai Dinas Pekerjaan Umum dan Penataan Ruang Kota Gunungsitoli slalu mengedepankan kedisiplinan kerja dalam menjalankan rutinitas sehingga dapat meningkatkan kinerja kerja masing-masing pegawai Dinas Pekerjaan Umum dan Penataan Ruang Kota Gunungsitoli. Hasil ini sesuai dengan penelitian yang dilaksanakan oleh Barsah (2020) yang menunjukkan disiplin kerja memiliki pengaruh yang positif dan terbukti signifikan terhadap kinerja karyawan.

\section{SIMPULAN}

Hasil penelitian menunjukkan secara parsial etos kerja berpengaruh langsung terhadap disiplin kerja pegawai Dinas Pekerjaan Umum dan Penataan Ruang Kota Gunungsitoli, secara parsial etos kerja berpengaruh langsung terhadap kinerja pegawai Dinas Pekerjaan Umum dan Penataan Ruang Kota Gunungsitoli, secara parsial disiplin kerja berpengaruh langsung terhadap kinerja pegawai Dinas Pekerjaan Umum dan Penataan Ruang Kota Gunungsitoli dan etos kerja berpengaruh terhadap kinerja melalui disiplin kerja pegawai Dinas Pekerjaan Umum dan Penataan Ruang Kota Gunungsitoli.

\section{DAFTAR PUSTAKA}

Amanahtuzuriah, A., Nurmadiah, N., \& Asmariani, A. (n.d.). PENGARUH KEPEMIMPINAN KEPALA SEKOLAH TERHADAP KOMPETENSI GURU DI SDN o35 TEMBILAHAN. 148, 148-162. http://ejournal.fiaiunisi.ac.id/index.php/alafkar/article/view/132

Andharini, S. N., Nurjannah, D., \& Kadharpa, E. (2016). KOMUNIKASI PEMASARAN JASA PADA PENDIDIKAN TINGGI DI MALANG. Seminar Nasional Dan Gelar Produk.

Bawelle, M., \& Sepang, J. (2016). Pengaruh Etos Kerja , Gairah Kerja dan Disiplin Kerja Terhadap Kinerja Karyawan PT. BRI Cabang Tahuna. Jurnal EMBA, 4(5), 353361.

https://ejournal.unsrat.ac.id/index.php/em ba/article/view/14120

Dewi, K., \& Utomo, H. (2015). Pengaruh Etos Kerja, Insentif dan Pengembangan Karir Terhadap Kinerja Karyawan Departemen Cutting PT Morichindo Fashion Ungaran. Among Makarti, 8(16), 55-64.

Hardiansyah, R. O. (2017). PENGARUH ETOS KERJA DAN DISIPLIN KERJA TERHADAP 
KINERJA PEGAWAI. UNIKOM, 87(1,2), 149-200.

https://repository.unikom.ac.id/id/eprint/2 570

Karundeng, C. C. (2013). Pengaruh Iklim Organisasi terhadap Karyawan pada PT. TASPEN (Persero) Cabang Manado. Jurnal Acta Diurna, 2(3), 1-15. https://ejournal.unsrat.ac.id/index.php/act adiurnakomunikasi/article/view/2433/1968

Manuho, E., Warouw, H., \& Hamel, R. (2015). HUBUNGAN BEBAN KERJA DENGAN KINERJA PERAWAT DALAM PEMBERIAN ASUHAN KEPERAWATAN DI INSTALASI RAWAT INAP C1 RSUP PROF. DR. R. D. KANDOU MANADO. Jurnal Keperawatan UNSRAT.

Murniaty, D., \& Absah, Y. (2012). PENGARUH IKLIM ORGANISASI TERHADAP KINERJA KARYAWAN BAGIAN PEMASARAN PADA PT TELKOM DIVISI TELKOM FLEXI MEDAN. 3(September), 119-122. https://docplayer.info/48656789-Pengaruhiklim-organisasi-terhadap-kinerjakaryawan-bagian-pemasaran-pada-pttelkom-divisi-telkom-flexi-medan.html

Nur, S., Ahmad, A., \& Vera, A. (2019). Hubungan Tingkat Stres Kerja dengan Kinerja Perawat di Ruang Instalasi Gawat Darurat RSU Kabupaten Tangerang. Jurnal JKFT, 4(1), 36-42.

http://jurnal.umt.ac.id/index.php/jkft/artic le/view/2005/1240

Putra, I. K. A. A. A., Syaifudin, A., \& Adinatha, N. N. M. (2014). Hubungan Gaya Kepemimpinan Kepala Ruangan Dengan Kinerja Pperawat Pelaksana Di Rumah Sakit Umum Daerah RAA Soewondo Pati. Prosiding Konferensi Nasional II PPNI Jawa Tengah 2014.

Robert Kreitner, A. K. (2014). Perilaku Organisasi. Salemba Empat. https://openlibrary.telkomuniversity.ac.id/

Sagala, S. (2018). Pendekatan $\mathcal{E}$ Model Kepemimpinan. Jakarta: Prenadamedia Group.

Setiawan, F., \& Dewi, A. (2014). Pengaruh Kompensasi Dan Lingkungan Kerja Terhadap Kinerja Karyawan Pada Cv. Berkat Anugrah. E-Jurnal Manajemen Universitas Udayana, 3(5), 252522.

Sugiarto, B. I. (2018). Kepemimpinan dengan Motivasi Kerja Perawat di Ruang Rawat Inap Penyakit Dalam. 1-130. sugus, permen. (2018). Teori kepemimpinan. https://doi.org/10.31219/osf.io/bzvqu

Yayuk, S., \& Sugiyono, S. (2019). Pengaruh kepemimpinan kepala sekolah dan biaya pendidikan terhadap kualitas proses belajar mengajar dan dampaknya dengan kompetensi lulusan SMK di Kabupaten Gunungkidul. Jurnal Akuntabilitas Manajemen Pendidikan, 7(1), 84-96. https://doi.org/10.21831/amp.v7i1.23758 